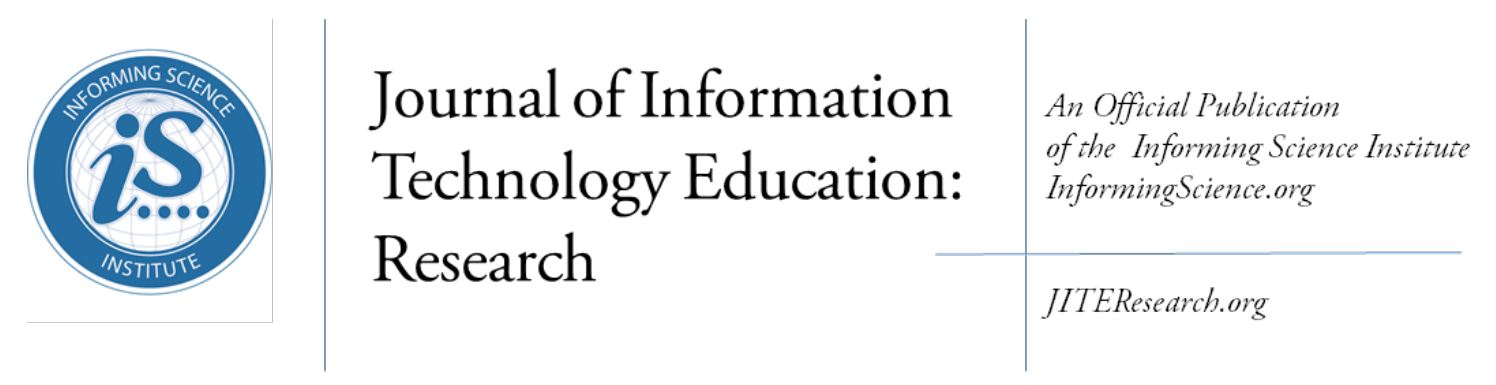

Volume 16, 2017

\title{
Google Docs as a ToOl For Collaborative WRITING IN THE MIDDle SCHOOL ClaSSROOM
}

Megan Woodrich

Yanan Fan*

* Corresponding author
San Francisco State University, San Francisco, CA, USA

San Francisco State University, San Francisco, CA, USA meganwoodrich@gmail.com

yanan@sfsu.edu

\section{ABSTRACT}

Aim/Purpose In this study, the authors examine how an online word processing tool can be used to encourage participation among students of different language backgrounds, including English Language Learners. To be exact, the paper discusses whether student participation in anonymous collaborative writing via Google Docs can lead to more successful products in a linguistically diverse eighthgrade English Language Arts classroom.

Background English Language Learners (ELLs) make up a considerable portion of elementary and secondary public school students, as language and ethnic diversity has become the norm in the United States. The research literature finds that ELLs are statistically behind their monolingual peers on such key language and academic development indicators as writing. Educators and researchers then turn to collaborative writing with the assistance of online technology. Although it is shown in literature to be a worthwhile endeavor for students of all ages and ability levels, no studies have investigated the differences it makes, namely, in comparison to traditional face-to-face collaboration in the classroom, and to anonymous online collaboration in the virtual space.

Methodology Through face-to-face, online, and anonymous writing activities, a rubric, and a survey, this quantitative study asks if anonymous collaborative writing, compared to other modalities, equalizes participation among students of varying language fluencies, and if anonymous collaborative writing, compared to other modalities, affect student comfort levels.

\footnotetext{
Accepted by Editor Jo Coldwell-Neilson | Received: February 6, 2017 | Revised: August 9, September 29, 2017 | Accepted: October 1, 2017.

Cite as: Woodrich, M., \& Fan, Y. (2017). Google Docs as a tool for collaborative writing in the middle school classroom. Journal of Information Technology Education: Research, 16, 391-410. Retrieved from http://www.informingscience.org/Publications/3870
}

(CC BY-NC 4.0) This article is licensed to you under a Creative Commons Attribution-NonCommercial 4.0 International License. When you copy and redistribute this paper in full or in part, you need to provide proper attribution to it to ensure that others can later locate this work (and to ensure that others do not accuse you of plagiarism). You may (and we encourage you to) adapt, remix, transform, and build upon the material for any non-commercial purposes. This license does not permit you to use this material for commercial purposes. 
Contribution This builds on research of online collaborative writing tools and suggests that using such tools (Google Docs in particular) is beneficial, especially for students who are building their language abilities. The study further reveals varied degree of success and student comfort level in participating writing tasks in three modalities.

Findings We ascertain that students of varying language fluencies participated more equally when they were able to remain anonymous. Face-to-face writing exhibited the highest overall scores, and students enjoyed working on Google Docs.

Recommendations Future and current teachers are encouraged to be open to new technologies and for Practitioners be creative in the use of technology to facilitate student learning. They should have the opportunity to participate in the discussion on how, not if, integrating technology impacts the cognitive, social, and cultural dimensions of teaching.

Recommendation After this initial quantitative study on students' reactions to various modalities for Researchers of technology-supported writing formats, the next questions to ask may be how students were engaging in dialogues during face-to-face sessions or chat features of Google Docs trials, and what types of edits students are making. Researchers should turn their focus on secondary school classrooms where there is an increasing impact of technology-assisted collaborative writing on student learning and teaching pedagogy.

Impact on Society As online technology has become an integral part of daily life, it is beneficial to educators, policy makers, and classroom teachers to understand how technology can be integrated in writing programs and to what extent the integration can help boost student motivation and participation.

Future Research More longitudinal research on online assisted collaborative writing and additional quantitative data are needed to further understand the complexities of the writing process in-group online writing and the nature of collaboration.

Keywords English language learners, writing instruction, technology, middle school, collaborative writing tools

\section{INTRODUCTION}

English Language Learners (ELLs, or Students whose first language is something other than English, as designated through the California English Language Development Test level) make up a considerable portion of elementary and secondary public school students, as language and ethnic diversity has become the norm in the United States. In the 2015-2016 school year, 1.374 million, or 22\%, of K-12 students in California were classified as ELLs, while an additional 1.3 million students were reclassified fluent English proficient, or RFEP, as they have subsequently met the English language proficiency criteria identified by their school districts (California Department of Education, 2015a). Still, the research literature finds that ELLs are statistically behind their monolingual peers on such key language and academic development indicators as writing (Aud et al., 2013) and in-class participation (N. Li, 2013), which in turn hinders their language growth (Cohen, Lotan, Abram, Scarloss, \& Schultz, 2002). For example, in 2011, the achievement gap between non-ELL and ELL students was 36 points (on a 500 point scale) at the 4th-grade level and 44 points at the 8th-grade level in measures of reading comprehension on the National Assessment of Educational Progress test. At both grade levels, this "achievement gap was not measurably different from that in any assessment year since 2002" (Aud et al., 2013). This illustrates that a large disparity exists between these sets of pupils, that ELLs as a group have not mastered these skills despite years of progress in educational methods and that, as students mature, the divide between non-ELLs and ELLs worsens. The problem is significant 
because a failure to adapt teaching practices to answer the needs of ELLs will result in a sustained achievement gap for all current and incoming students.

Getting ELLs up to speed in English language arts has traditionally been addressed with such strategies as pairing pictures with instruction, coordinating vocabulary terms with physical movement, and asking students to speak with a partner before writing or responding verbally to the class as a whole. However, these strategies are not always effective in facilitating academic language development or improving written expression $(\mathrm{N}$. Li, 2013). Educators and researchers then turn to collaborative writing projects or assignments that require students to work together and use one another's strengths to craft a shared text. This process reflects learning to write as a social practice where writers share experiences and create meaning through writing (Dyson, 2016), and offers the potential to increase both group and individual learners' literacy skills (e.g., Suwantarathip \& Wichadee, 2014). Yet, educators contend with creating conditions in which learners can participate without feeling anxious or incapable, especially within heterogeneous groupings (Dobao, 2012; Kessler, Bikowski, \& Boggs, 2012; Wigglesworth \& Storch, 2009).

Many turn to online technology, which has become an inseparable part of contemporary life in and out of the classroom. Among discussions of using technology in classrooms, its advantage of reducing students' anxiety in such areas as writing (e.g., Shang, 2013) or test taking (e.g., Sun, 2014) is noteworthy, as well as boosting student outcomes (O’Dwyer, Russell, Bebell, \& Tucker-Seeley, 2005). In many states, one clear push for integration of technology in language classrooms is the adoption of the Common Core State Standards (National Governors Association Center for Best Practices \& Council of Chief State School Officers, 2010), which require basic technological proficiency among all students when they complete online academic tasks (writing in particular).

In order to make the curriculum accessible for ELLs, educators must embrace such technological integration and innovation in literacy and writing instruction that diminish status issues, allow students to scaffold the material for one another, and provide opportunities for timely feedback (Asterhan, Schwarz, \& Gil, 2012; Cohen et al., 2002). Although collaborative writing with (or without) the assistance of online technology is shown in literature to be a worthwhile endeavor for students of all ages and ability levels (Dobao, 2012), no studies have investigated the differences it makes, particularly in comparison to traditional face-to-face collaboration in the classroom, and to anonymous online collaboration in the virtual space.

This paper discusses whether student participation in anonymous collaborative writing via Google Docs can lead to more successful products in a linguistically diverse eighth grade English Language Arts classroom. To be exact the questions that guided this research are:

1. Does anonymous collaborative writing, compared to other modalities, lead to more successful products?

2. Does anonymous collaborative writing equalize participation among students of varying language fluencies?

3. Does anonymous collaborative writing affect student comfort levels?

\section{LEARNING TO WRITE WITH TECHNOLOGY}

We are guided by a sociocultural perspective that views language learning as a social practice in which members of a writing community play active roles in sharing experiences and responding to other members (Hymes, 1974; Vygotsky, 1978). Online technology, which is integral to communication and language learning in contemporary society, mediates the writing process by creating not only virtual cross-cultural communities of practice (Warschauer, 1997), but also conditions for effective group interactions to occur among members who shared cognitive, emotional, and motivational investment (Dillenbourg, Järvelä, \& Fischer, 2009). Collaboration under this social and technological learning 
environment indicates shared purposes of writing, negotiation of ideas in decision making, and a joint writing product (Hennessy, Deaney, \& Ruthven, 2005; Wong, Chai, \& Aw, 2017).

\section{COLLABORATIVE WRITING AMONG LANGUAGE LEARNERS}

Collaborative writing tasks require students to work together to produce a shared text. In groups, students scaffold tasks for one another and achieve a more developed product than the ones from individual work (Chang \& Simpson, 1997; Jones, 2007). The benefit of collaborative tasks is particularly true for students who learn English as a second language in academic settings. Studies show that when they work together to draft research papers, they share their thinking space and offer revision suggestions that focus on meaning (Kessler et al., 2012). Wigglesworth and Storch (2009) compared texts written by over a hundred first-year Asian students (some in pairs; other individually) in an Australian university. Through an analysis of the accuracy, fluency, and complexity of the argumentative essays students wrote on an assigned topic - the advantages and disadvantages of exam-based assessment - the researchers suggest that students writing in pairs tend to produce more grammatically accurate texts and spend longer time negotiating and scaffolding the content as compared to those writing individually. Another comparison made by Dobao (2012) of the writings of college Spanish language majors working individually, in pairs, and in groups on the same task reveals similar positive outcomes for pairs and groups in face-to-face collaboration and problem-solving. Despite the differences in design and methods, the studies advocate for the use of collaborative writing in the ELL classroom. Working as an ensemble allows students to pool their writing resources, test their ideas safely, and actively participate in the process.

\section{COLLABORATIVE TECHNOLOGIES IN WRITING CLASSROOMS}

Over the past decade, many collaborative web second-generation tools (Google Docs, Wiki, etc.) have entered language classrooms and have been redefining the dynamics in interactions among members of the class. These tools are designed to be highly interactive and collaborative as they provide multiple writers with the virtual space to contribute to an evolving text (Hadjerrouit, 2011). In other words, "The affordances of social digital networks enable people to work together on projects in ways not necessarily possible in the past due to distance, time, age, or language constraints" (Coiro, Knobel, Lankshear, \& Leu, 2008, p. 527). Early research shows that online networks of collective authoring and idea-processing tools can facilitate student learning (Dishaw, Eierman, Iversen, \& Philip, 2013; Wyatt-Smith \& Elkins, 2008). Being developed at an unprecedented fast pace nowadays, technology software offers innovative ways to streamline the collaborative writing process, encourage more sophistication and better accuracy in student writing, and facilitate timely, valuable feedback from one member to the other (Liu \& Lan, 2016). For instance, a review of technology in foreign language classrooms finds that a wiki can support open-editing of content, enable collaboration on in-class projects, and help students and teachers to find information (Golonka, Bowles, Frank, Richardson, \& Freynik, 2014). Web-based writing tools, such as Google Docs, extend classroom interactions to out-of-class, where college students, who often have difficulties meeting face-to-face, work on their collaborative writing projects with ease and efficiency (Davey, Bozan, Houghton, \& Parker, 2016; Seyyedrezaie, Ghonsooly, Shahriari, \& Fatemi, 2016; Zhou, Simpson, \& Domizi, 2012).

Quite a few studies focus on the impact of technologies on aspects of writing and writing instruction. For example, Suwantarathip and Wichadee (2014) examined the impact Google Docs may have on student writing in a Thai university, as well as the nature of student cooperation in Google Docs work groups. The quantitative study found that students who commented and critiqued each other's work via Google Docs gained a greater understanding of the writing process in general and performed better on an individual post-test than those students who had been in face-to-face groups. This study implies that Google Docs can be used productively to increase students' writing abilities, and that those improvements can be seen even on the individual level. 
Similarly, Kessler et al. (2012) investigated 38 Fulbright scholars' engagement in writing online and the group participation pattern in relation to their completing the research report project in their second language. They found that with the web-based word processing tool, the writers developed various levels of participation and successfully facilitated each other's writing through feedback given on the virtual platform.

While much research has been done that shows that students benefit from peer interaction enabled by technology, Asterhand et al. (2012) study how instruction and teacher feedback in an online environment would affect the writing products created by the students. Comparing groups of 9th grade Israeli schoolchildren who received varied amounts of teacher guidance while using an online discussion/writing tool, the researchers put forth that students who were given clear guidance on composing and communicating the writing products produced more connectivity in their arguments and were more collaborative and helpful to one another. The researchers suggest that synchronous teacher moderation in online environments is extremely useful for helping young people engage in effective discussions, and that the effects of gender cannot be ignored.

\section{STUDENT COMFORT IN ONLINE COLLABORATIVE LEARNING}

Other researchers focus on the relationship between technology and students' sense of comfort and achievement, as writing anxiety can be pervasive among second or foreign language learners and can impact their competence and confidence in English (Shang, 2013). For instance, Suwantarathip and Wichadee (2014) observed that students who used Google Docs were confident in sharing their ideas with others. Kessler et al. (2012) note through a survey that students felt that each member of the group had contributed and had a valuable role when working online. Kennedy and Miceli (2013) report a stronger sense of community among those working together via online technology. Zhou et al. (2012) argue that web-based writing technology (e.g., Google Docs) significantly altered the collaborative processes of participating college undergraduates. These students reported that the tool helped them communicate more easily with one another and write with less anxiety. However, such promising results would not be possible without first training students to use the technology, as familiarity with the tools is a key factor in student perception of the collaboration (Brodahl, \& Hansen, 2014). Some findings were less positive. The student survey results from Brodahl, Hadjerrouit, and Hansen (2011) seem to reflect a lack of student confidence with the digital tools, and Zhu (2012) noticed compelling evidence that cultural differences affected student perceptions of the digital environment after comparing how first year Chinese and Flemish undergraduates contribute to online discussion in their respective countries.

Even though a review shows that technology has a history of benefiting second language writing (Kessler et al., 2012) and that online collaborative writing increases student perceived comfort levels when working in this domain, none had looked at how these new tools impacted participation specifically. None accounted for the possibility that students were conversing offline, nor did any of the researchers compare the comfort levels of individual students (or ELLs specifically) across media. None had included a trial that allowed students to be anonymous within an online platform (e.g., Google Docs), nor how the comfort experienced therein may influence group participation and scores. Finally, none of this work had ever been done with middle school ELL students as far as the researchers are aware.

There remains a gap in the literature as to how in-person collaborative writing products compare to those which were created online (both anonymously and with names), which leads to our research question: Does anonymous collaborative writing via Google Docs lead to more successful products in a linguistically diverse eighth grade English Language Arts classroom? This would be the true test of an online tool's ability to increase comfort level and the potential for achievement, particularly for language learners. Educators in the twenty first century have many tools available and using these tools to guide the burgeoning population of ELLs in writing is crucial to their language development. 


\section{CONTEXT OF STUDY}

This quantitative study took place in three $8^{\text {th }}$ grade English Language Arts classrooms at Mulberry Avenue Middle School (MAMS, a pseudonym), a Title I program Improvement public school during the 2015-2016 school year. According to the California Department of Education, the Title I law "provides financial assistance to local educational agencies and schools with high numbers or high percentages of children from low-income families to help ensure that all children meet challenging state academic standards" (California Department of Education, 2015b). The Program Improvement designation is applied to any school which, for two consecutive years, does not meet their Adequate Yearly Progress goals on standardized testing as determined by the state. Such schools receive additional support and monitoring for five years. These school sites are also required to create a comprehensive school wide plan for improvement and provide supplemental educational services, or free tutoring, to low-income students enrolled in the school.

MAMS serves some 600 students in grades 6-8 in an industrial city district in Northern California. Approximately $30 \%$ of students at MAMS are classified as ELLs, and an additional $45 \%$ of students as RFEP. The participants in this study were 97 eighth grade students (49 females and 48 males; 16 ELLs and 15 RFEP) from a diverse background, who were placed randomly in three English Language Arts classes taught by the same teacher at MAMS. Among these students, 59 identified Spanish as their primary language. Other languages included Tagalog, Arabic, Cantonese, Punjabi, Hindi, and Urdu. Within this group, 18 students were registered for free and reduced lunch, an indicator of low socioeconomic status. Seven students had Individualized Education Plans (IEP) for Special Education services. Most students had limited access to computer technology in the classroom and at home, but they had experience working with Google Docs individually and in groups prior to the administration of the research trials and were familiar with similar word processing tools from other classes or years of school.

\section{RESEARCH DESIGN}

We randomly assigned the participants into balanced collaborative groups of four based on their ELL or RFEP designation. As shown in Table 1, we included three distinct writing prompts delivered over three trials, structured such that no class period experienced the same sequence of modalities (Online, Face-to-face, then Anonymous Online), though the topics remained in order. "Class Period 1 " refers to the set of students that meets together during the first period of the school day. During their unit, student groups in Class Period 1 first wrote about "Topic A" in a "Face-to-face" setting, later wrote about "Topic B" using the "Online" tool (Google Docs), and finally used Google Docs in an "Anonymous Online" fashion to write about "Topic C." Student groups changed between trials, but at no time were students grouped with anyone from a different Class Period.

Table 1. Sequence of events

\begin{tabular}{|l|l|l|l|}
\hline & Trial 1 - Topic A & Trial 2 - Topic B & Trial 3 - Topic C \\
\hline Class Period 1 & Face-to-face & Online & Anonymous Online \\
\hline Class Period 2 & Anonymous Online & Face-to-face & Online \\
\hline Class Period 3 & Online & Anonymous Online & Face-to-face \\
\hline
\end{tabular}

Student work was evaluated using a teacher-generated rubric with the help of two additional teachers who served as graders. Students were scored according to their mastery of the eighth-grade Com- 
mon Core State Standards for California. As a culmination to the writing experience, students completed a reflective Likert scale attitudinal survey. Furthermore, the Online and Anonymous Online trials were analyzed to determine how many contributions each student made, which were then calculated into participation percentages for each individual within the group members. The Face-to-face trials, in which students wrote with different colored pens on paper, were also analyzed to determine what percentage of writing was completed by each individual.

The writing task in all three modalities was an "AXES", an acronym for the paragraph structure of Assertion, eXample, Explanation, and Significance particularly adapted by the department for argumentative or persuasive paragraphs with a rubric.

These three tasks asked students to write characterization inferences from the class text "The Diary of Anne Frank" by Frances Goodrich and Albert Hackett. Each trial focused on a separate character, and students were asked to draw evidence from the text to support their ideas about the character (See Appendix A for full assignments). Students were familiar with this writing style, but needed continued practice communicating their thoughts in academic writing, especially as the source texts in class become more complex.

\section{DATA COLLECTION AND ANALYSIS}

Data Collection occurred in Spring 2016. Prior to the 3-week long formal data collection, all students participated in two assignments using Google Docs in order to become familiar with the platform and its tools. One assignment was an individual Reader Letter (Appendix B) in which students described their reading habits, while the other was a group assignment that required students to write a news article from a biased perspective (Appendix C). Students were instructed on how to type, edit text, comment, resolve comments, and use the chat feature. Furthermore, each student reviewed how Google Docs saves all of their work and records their drafts after they have erased them. The class reviewed the rubric (Appendix D) and a sample paragraph to model the expected outcomes of the assignment.

The Google Chrome add-on "Doctopus" was used to send assignments to students in specific groups. Doctopus distributes documents automatically depending on user settings, allows only members of the group to see the document, and allows the instructor to "embargo" or lock docs for grading, which ensures that all groups receive the same amount of time.

Three types of data were collected for this study. First, student participation within the face-to-face groups was measured through individual students' use of colored pens. For both the Online and the Anonymous Online trials, the Google Docs revision history was used to determine the authorship of each piece of text by color. This data was analyzed for number of contributions. Therefore, each method of writing was analyzed to understand who wrote which pieces of text.

During data collection, students sat either in tables (for face-to-face) or at individual desktop computers (for both anonymous and non-anonymous Google Docs trials). Students were instructed to conduct all of their planning via the chat feature in order to remain silent during the Google Docs trials. Students were not seated with their groups in the computer lab; therefore, it was ineffective for students to verbally discuss their paragraphs. The first author of this paper required interactions among members of the group to happen via the chat feature in order to encourage students to take advantage of this online feature, as it is also part of Google Docs.

To set up the Anonymous Online option, special instructions were included at the start of the assignment not to share names with one another. It was important that students not share their identities because this could compromise the data and potentially lead to a raised affective filter in those students whose names were known. Students were given 45 minutes during one class period to work on each paragraph. At the stopping point for each day, the first author of this paper embargoed the 
digital documents and collected the face-to-face documents to prevent further edits made after class time.

Second, each piece of student writing, upon completion, was scored against a rubric generated by MAMS' English Language Arts Department. A second reader corroborated each score, and for any papers that received drastically different results, a third reader was called in. The additional readers were a fellow eighth grade English Language Arts teacher at MAMS, and a seventh-grade teacher who was also the co-department chair of the English Language Arts department. Both graders were selected for their experience and consistency in scoring student writing and for their familiarity with the project goals. The two additional graders did not participate in the data analysis of the research.

The final piece of data is the five point Likert scale Attitudinal Survey (Appendix E), which was administered anonymously after all classes had completed the three trials. Students were offered nominal class credit for the writing products and the survey.

After three weeks of data collection, 850 student scores were relevant to this research. Over nine total trials, 28 data points were omitted due to absences and dropped students. Four additional scores from the Anonymous Online trials were discarded after concerns of plagiarism.

We recognized that the results may not be generalizable beyond the specific population and conditions at MAMS. Classes were at varying points during the day, which could affect students' focus or comprehension. Computers, children, absences, and even noise from outside the classroom are unreliable and unpredictable, but we made every effort to design this study such that there are few internal threats to validity. The students in each class period progressed through topics in the same order, but not the modalities. Therefore, the measurements of success should indicate the strengths and weaknesses of the modalities and not those of the differing prompts.

Data was analyzed in three ways. For the survey, each Likert response was averaged to find the students' overall reaction to each question. For the writing responses, we scored each paragraph using the rubric. To operationalize student participation in this quantitative study, we counted the number of words they had written on the face-to-face document in their color and compared students in each group with percentages. For the digital documents, the Google Docs revision history allowed us to see which student had contributed which words, and these were also calculated with percentages within groups to determine participation. The analysis can be limited in the scope and type of revisions that are credited to students, as the study makes no attempt to distinguish between grammatical fixes, spelling fixes, planning participation, writing participation, or silly revisions in either face-toface or Google Docs. While this may be interesting to note, such a coding system was not feasible within the scope of this study. We also found the mean of all scores for all three writing prompts and modalities. We carried out an ANOVA to analyze the variance between modalities so we could determine if the modality made any difference in the overall writing score or in student participation.

\section{FINDINGS}

\section{SUCCESS OF STUDENT PRODUCTS ACROSS MODALITIES}

The first question in this research is: In a linguistically diverse eighth grade English Language Arts classroom, does anonymous collaborative writing lead to more successful products? If the answer is positive, we expect to see a greater mean writing score from the Anonymous trials than from the Online or Face-to-face trials. As mentioned previously, each class period progressed through the modalities in a different order, although the topics in each trial remained in a fixed order throughout. Figure 1 shows that neither the order nor topic seemed to dictate student scores, which varied across trials and modalities although there were statistically significant differences between writing scores by both order (class period with an ANOVA F-ratio of 5.14, $\mathrm{p}=.006^{* * *}$ ) and topic (ANOVA F-ratio = $\left.5.42, \mathrm{p}=.005^{* * *}\right)$. 


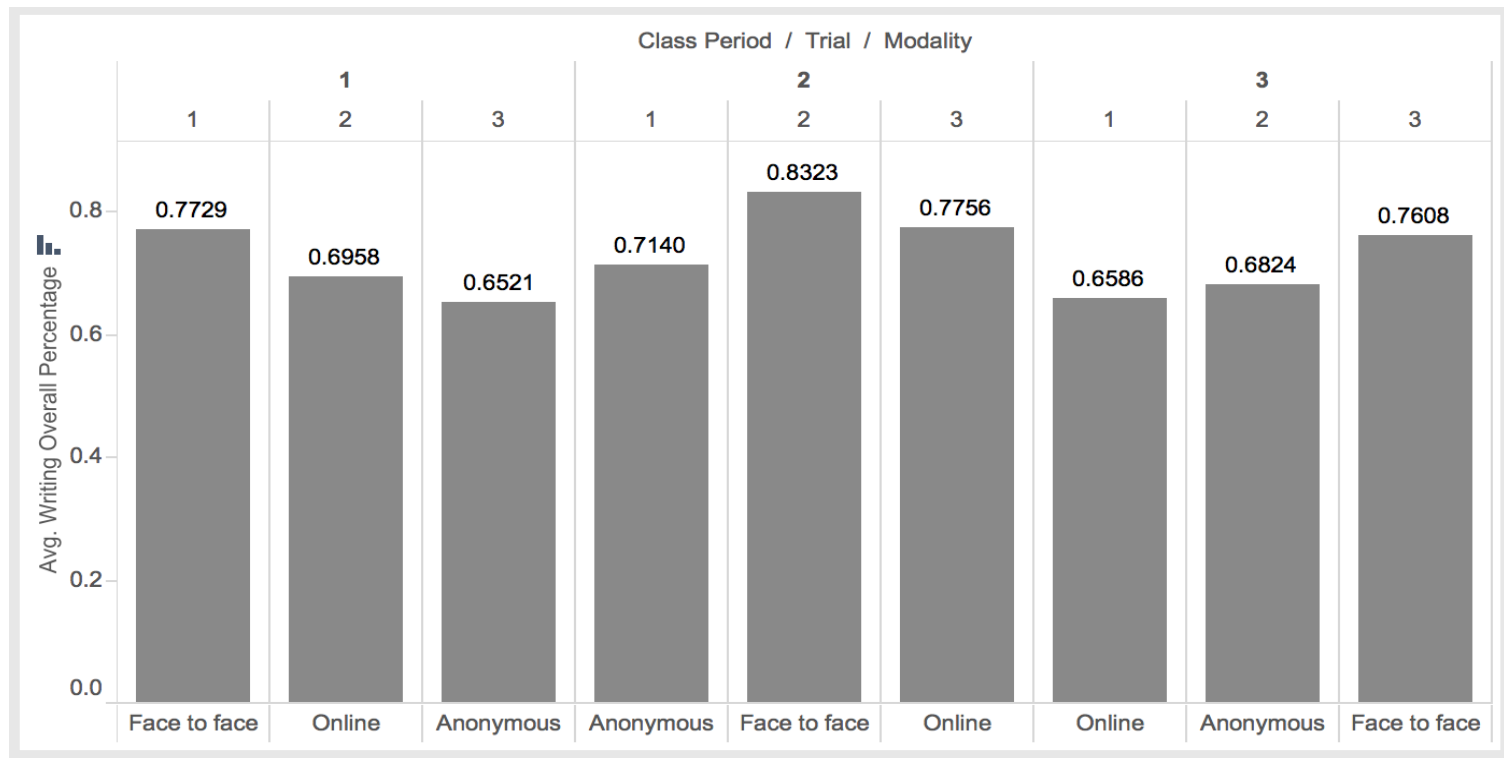

Figure 1. Average writing scores in each class period per trial

The best and worst average writing performance happened in different trials for each class period, which demonstrates that the students were not significantly better in the later trials simply because of maturation.

Analysis of the data when modality and overall writing score are compared reveals other phenomena. Figure 2 displays the range of scores within each modality. The juncture between light and dark grey ranges reveals the median score of data within the modality.

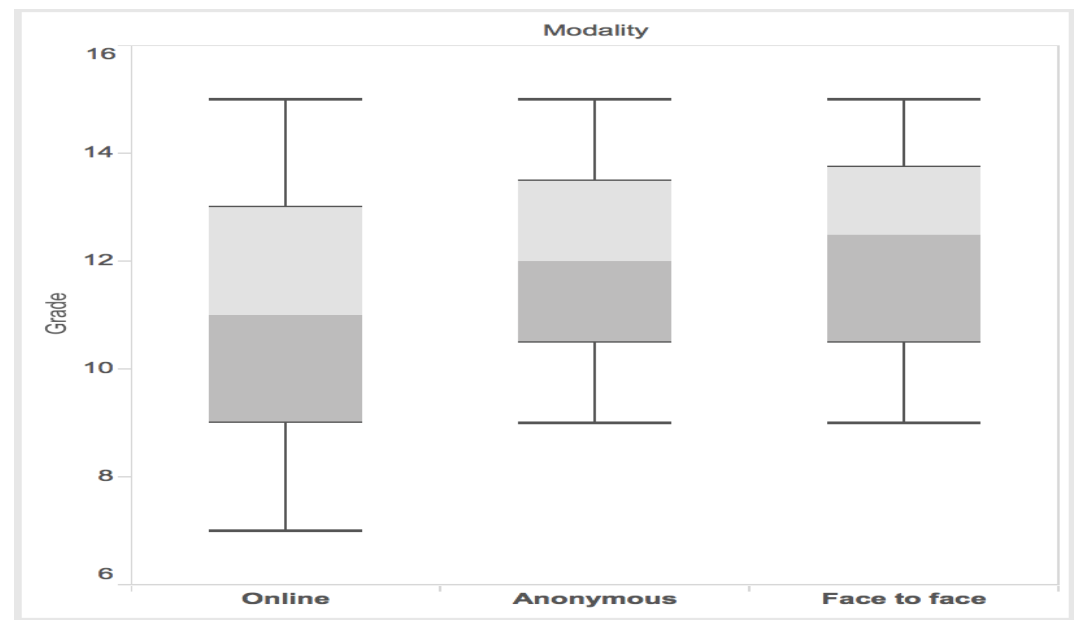

Figure 2. The range of scores and the median within each modality

When grouped not by class period but by modality, the numbers show that the highest median score of 12.46 out of a possible 15 (or 83.06\%) was achieved through Face-to-face trials. Anonymous Online trials were a close second with a mean score of 11.94 (79.60\%), and Online trials produced by far the worst scores (a mean of 11.02, or $73.36 \%$ ) and the widest range of scores (spanning from a score of 7 , or $46.66 \%$, to that of 15 , or $100 \%$ ).

However, this analysis of variance of the average writing score for each of the groups working within each modality shows that the differences between the groups are statistically significant $(\mathrm{F}=8.02$, $\mathrm{p}=.000)$. 
Table 2. Analysis of variance results for differences between groups

\begin{tabular}{|l|l|l|}
\hline Dependent Variable by Modality & F-Ratio & $\begin{array}{l}\mathrm{p} \text { - value (Significance } \\
\text { of Difference Between } \\
\text { Groups: F-Ratio) }\end{array}$ \\
\hline Overall Writing Score by Modality & $\mathrm{F}=8.02$ & $\mathrm{p}=.000$ **** \\
\hline Percent of Participation by Modality & $\mathrm{F}=0.31$ & $\mathrm{P}=.736$ \\
\hline \multicolumn{2}{|c|}{$\mathrm{p}>=.05 * / \mathrm{p}>=.01 * * / \mathrm{p}>=.001 * * * / \mathrm{p}>=.000 * * * *$} \\
\hline
\end{tabular}

This indicates that writing with each of these types of modalities makes a significant difference in the quality of writing: students using the Face-to-face method had the strongest overall score while students using the Anonymous methodology were slightly lower; the online method produced the lowest quality of the three.

Lastly, while students used the same type of notes for each document, those in the Face-to-face groups were able to compare notes prior to writing. Online and Anonymous Online groups were unable to do this because of proximity and anonymity constraints. It is difficult to know if and how the sharing of notes may have affected these scores. Overall, collaborative writing in an anonymous format does not improve writing scores when compared with Face-to-face methods.

\section{PARTICIPATION ACROSS MODALITIES AND STUDENTS}

The second question of this study is: Does anonymous collaborative writing, compared to other modalities, equalize participation among students of varying language fluencies? To gauge this, each student's participation was calculated in terms of a percentage of the group. For the face-to-face documents, each student's word count in different colored pens was used to determine their individual contributions. In both the Online and Anonymous Online documents, we examined the Google Docs revision history to see how many contributions each student had made to the document. Figure 3 depicts the overall percentage of contributions and variances across each modality. Each student's data points from all three trials are included in this data.

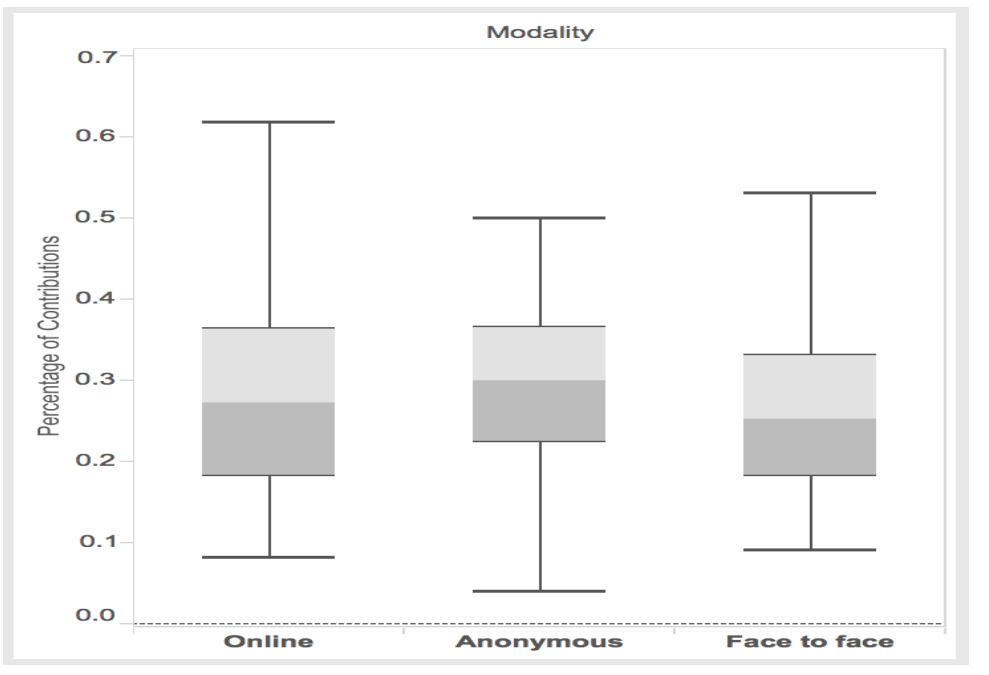

Figure 3. Overall percentage of contributions across modalities

During these three trials, students worked in groups of four. Thus, for completely equal participation, we would expect to see that each student is contributing one fourth (or 25\%) of the document. On the outset, Face-to-face trials were the most equal, given that the mean percentage of contributions hovers around $26.31 \%$. 
Online trials show a similar result with a mean percentage of contributions at $28.04 \%$, although there is more variance within these scores, with at least one student writing over $60 \%$ of the group's document. There is no clear explanation for this wide span of contribution scores, but it may be due to some students compensating for group members who were distracted by their friends in the chat feature or otherwise not helping on the document.

Finally, the average student in the Anonymous Online trials contributed $29.52 \%$ of the document, while his or her teammates wrote less. The lowest participation score overall occurs in the Anonymous Online trial, with one student who contributed only 5.08\% to the team's collaborative writing. Alternatively, teams may have had a harder time delegating the work. The true cause of this high standard deviation is, unfortunately, unknowable within the confines of this study, calling for further research especially within the anonymous writing modality.

Overall, there were no statistically significant differences in student participation by modality (ANOVA F-ratio $=0.31$, p. 736$)$ (Table 2$)$. This data shows that face-to-face writing is still the best way to encourage equal participation amongst group members, possibly because they can hold one another accountable while working in this manner, but the differences are not statistically significant. This finding goes against what we expected to see, which was that student participation would be more equal in both the Online and Anonymous Online trials.

To truly understand how students of varying language fluencies fared within their groups in terms of participation, Figure 4 shows how ELL and RFEP students compare to those with no designation (monolingual English speakers or otherwise unclassified within the school system).

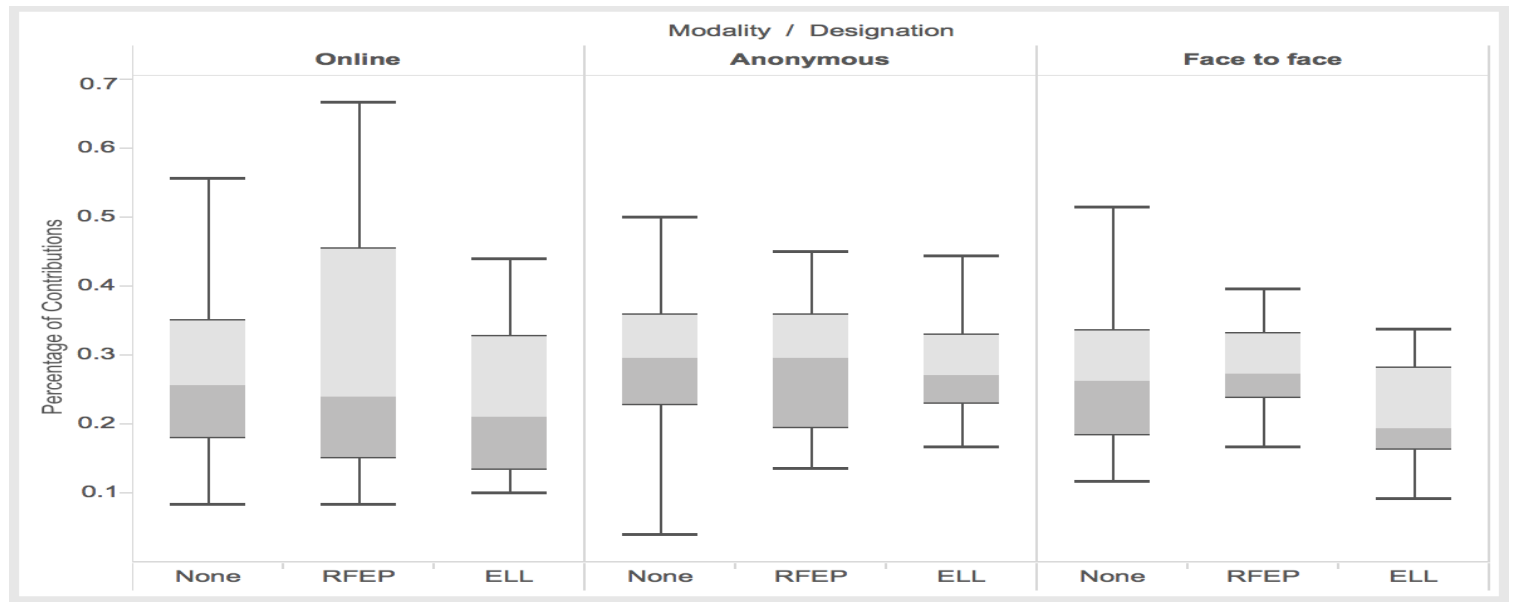

Figure 4. Student participation as expressed by a percentage and seen across modalities

Figure 4 shows, through the median measure, that ELL students and RFEP students contributed greater portions of the documents in the Anonymous Online writing trials than in either the Online or the Face to trials. Face-to-face trials show the greatest disparity between ELL students and those with no designation. Perhaps ELL students were less confident in their abilities in a Face-to-face setting, and therefore, they contributed less. As such, Anonymous Online trials do appear to equalize participation among students with varying language fluencies.

Finally, because ELL students were participating more in the Online and Anonymous Online trials, and because ELL students are typically less proficient in writing than their peers, it is possible that the decreased scores in these two areas (as seen earlier in Figure 2) are a direct result of increased ELL collaboration. 


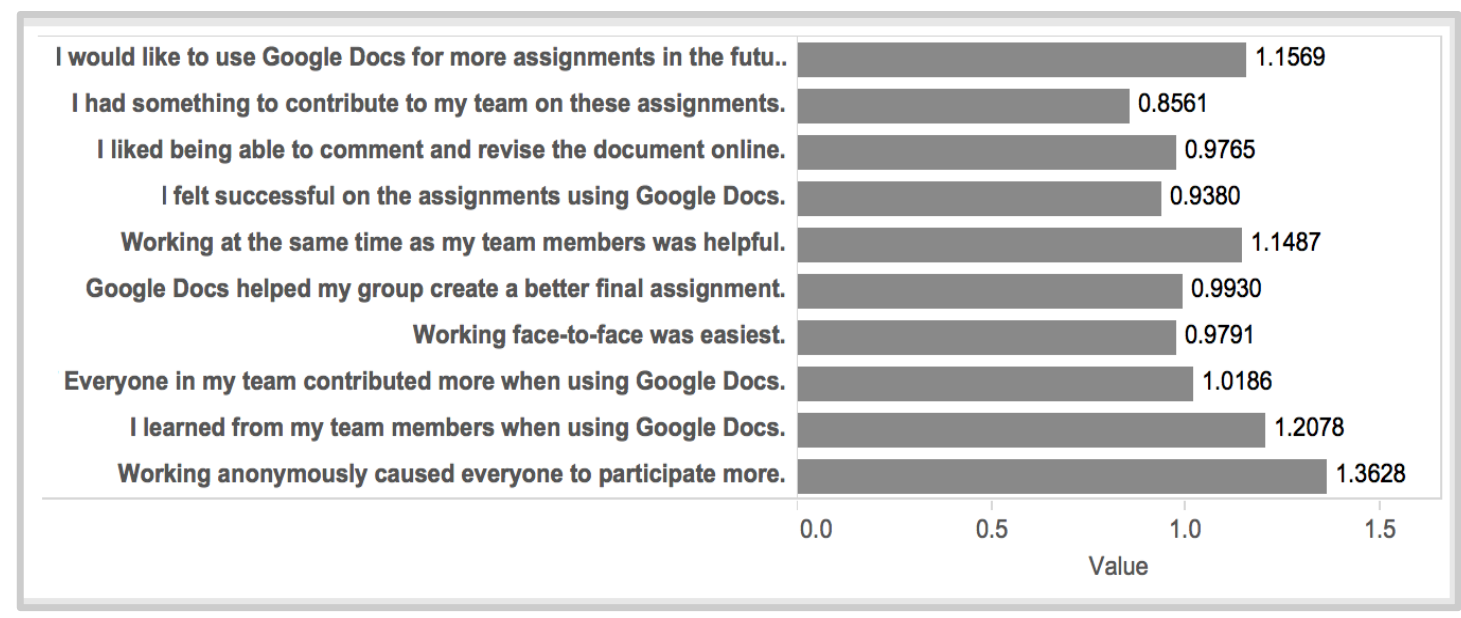

Figure 6. Standard deviation for each survey item

These results suggest that some students are intrigued by Google Docs and can see the potential for its use in further classroom work, but a smaller number remain less impressed. Students overwhelmingly agreed that they each had something to contribute on the assignments, which is positive news for teachers and researchers looking to explore this medium in the future.

Interestingly, responses to "Working anonymously caused everyone to participate more," produced the highest standard deviation at 1.3628, indicating that while many students saw this modality as the worst for collaboration, there was an observable amount of disagreement. It would be helpful for future studies to know how ELL and RFEP students were responding to these prompts. It may be the case that the wild variance of this last survey item is due to a difference in opinion among students with varying language fluencies.

\section{DISCUSSION}

This study in an eighth-grade English Language Arts classroom builds on research of online collaborative writing tools and suggests that using such tools (Google Docs in particular) is beneficial, especially for students who are building their language abilities. The study does not wholly agree with other studies in terms of Google Docs as a tool for success; instead, it reveals that anonymous collaborative writing via Google Docs does not lead to more successful writing products. Face-to-face documents herein received higher average and statistically significant scores compared to Anonymous Online and Online documents. This is in contrast, for example, to Suwantarathip and Wichadee's research (2014), which found that students in face-to-face feedback groups performed worse than those who had used Google Docs for the same processes, or to Kessler et al. (2012), who maintained that working online allowed collaborative groups to scaffold the task for one another, leading to a strong outcome. Differences in design, population, and task may explain the variety of results.

Anonymous collaborative writing, when compared to other modalities, promotes participation among ELL and RFEP students, though the relationship between their participation and the average document scores remains to be seen in further research. These results indicate that although face-toface documents earned better overall scores, the use of Google Docs to increase participation among students of varying language fluencies cannot be ignored.

Lastly, the results from this study suggest that anonymous collaborative writing may lower students' affective filters, which is consistent with some previous measures of student perceptions of Google Docs. Herein, the majority of students conveyed their interest in Google Docs and hoped to contin- 
ue working with it in the future. Much of the existing literature agrees that students working on Google Docs were satisfied with the process.

\section{CONCLUSION}

The present study was the first of its kind, to the researchers' knowledge, in comparing documents that were written in a face-to-face setting to those written online in an effort to investigate the opportunities online technology brings to writing instruction. It was also the first research to examine this phenomenon with middle school students of varying language fluencies. The study fills the significant gap in literature on ELL participation within a collaborative online group by indicating that these students participate more equally with their peers when they are contributing anonymously using digital tools. This work, while limited in scope and not conclusive by any means, offers a glimpse into a new field of education: one that leverages technology to benefit students of all backgrounds.

This research opens the door for more primary and secondary educators to utilize Google Docs in their classrooms in the future. Although the Face-to-face trials in this study produced the best written documents, the use of technology in this process is not a complete loss. Continued work with this digital medium may result in higher document scores as students become more versed in the available tools. The current study also examined how to engage ELL and RFEP students in peer work, and the results demonstrate that significant gains can be made for these students when they are anonymous. Future and current teachers are encouraged to be open to new technologies and creative in the use of technology to facilitate student learning. They should have the opportunity to participate in the discussion on how, not whether, to integrate the cognitive, social, and cultural dimensions of adopting technology in teaching.

After this initial quantitative study on students' reactions to various modalities of technologyinvolved writing formats, the next questions to ask may be how students of all language fluencies were engaging in dialogues during face-to-face sessions or chat features of Google Docs trials, what types of edits students are making (rather than just broad percentages of contributions), how the students appropriate Google Docs in ways that allow them to make meaning from their online interactions, and how students' individual writing abilities may have evolved over the long term when using Google Docs in a collaborative fashion. Researchers should turn their focus on secondary school classrooms where there is an increasing impact of technology-assisted collaborative writing on student learning and teaching pedagogy. More longitudinal research on online assisted collaborative writing and additional quantitative data are needed to further understand the complexities of the writing process in the group online writing and nature of the collaboration.

Developing literacy skills is situated in the on-going dynamics of writers, values, interactions, and various uses of technology as tools or resources. From elementary school students developing friendship while learning to write on computers (Vass, 2002), to immigrant adolescents choice of "communicative repertoires" in digital writing practices (Lam, 2009), to foreign language students interacting in group settings (M. Li \& Zhu, 2013), there is a wealth of opportunities for researchers and educators to examine the learning opportunities technology brings to traditional classroom setting. As online technology has become an integral part of daily life, it is beneficial to educators, policy makers, and classroom teachers to understand how technology can be integrated in writing programs and to what extent the integration can help boost student motivation and participation at all levels.

\section{ACKNOWLEDGEMENT}

We send a heartfelt thank you to Genie Stowers, Professor of Public Administration at San Francisco State University, for helping us tame the quantitative data. We also appreciate feedback and suggestions from Maika Watanabe, Professor in the Department of Secondary Education at San Francisco State University, on an early version of this study. 
Woodrich \& Fan

\section{REFERENCES}

Asterhan, C. C., Schwarz, B. B., \& Gil, J. (2012). Small-group, computer-mediated argumentation in middleschool classrooms: The effects of gender and different types of online teacher guidance. British Journal of Educational Psychology, 82, 375-397. doi:10.1111/j.2044-8279.2011.02030.x

Aud, S., Wilkinson-Flicker, S., Kristapovich, P., Rathbun, A., Wang, X., \& Zhang, J. (2013). The condition of education 2013 (NCES 2013-037). U.S. Department of Education, National Center for Education Statistics. Washington, DC. Retrieved from http://nces.ed.gov/pubs2013/2013037.pdf

Brodahl, C., Hadjerrouit, S., \& Hansen, N. K. (2011). Collaborative writing with web 2.0 technologies: Education students' perceptions. Journal of Information Technology Education: Innovations in Practice, 10, 73-103. Retrieved from https://brage.bibsys.no/xmlui/bitstream/handle/11250/138167/Brodahl_2011_Collaborative.pdf?seque nce $=1$ \&is Allowed $=\mathrm{y}$

Brodahl, C., \& Hansen, N. K. (2014). Education students' use of collaborative writing tools in collectively reflective essay papers. Journal of Information Technology Education: Research, 13, 91-120. Retrieved from https://www.informingscience.org/Publications/1960

California Department of Education. (2015a). Facts about English learners in California - CalEdFacts. Retrieved from http://www.cde.ca.gov/ds/sd/cb/cefelfacts.asp

California Department of Education. (2015b). Improving basic programs operated by local educational agencies (Title I, Part A). Retrieved from https://www2.ed.gov/programs/titleiparta/index.html

Chang, E., \& Simpson, D. (1997). The circle of learning: Individual and group processes. Education Policy Analysis Archives, 5, 7, 1-21. Retrieved from http://dx.doi.org/10.14507/epaa.v5n7.1997

Cohen, E., Lotan, R., Abram, P., Scarloss, B., \& Schultz, S. (2002). Can groups learn? Teachers College Record, 104, 1045-1068.

Coiro, J., Knobel, M., Lankshear, C., \& Leu, D. J. (2008). Introduction to part IV: Popular culture, community, and citizenship. In J. Coiro, M. Knobel, C. Lankshear, \& D. J. Leu (Eds.), Handbook of research on new literacies (pp. 523-529). New York: Lawrence Erlbaum.

Davey, B., Bozan, K., Houghton, R., \& Parker, K. R. (2016). Alternatives for pragmatic responses to group work problems. Informing Science: The International Journal of an Emerging Transdiscipline, 19, 89-102. Retrieved from http://www.informingscience.org/Publications/3504

Dillenbourg, P., Järvelä, S., \& Fischer, F. (2009). The evolution of research on computer-supported collaborative learning. In N. Balacheff, S. Ludvigsen, T. de Jong, A. Lazonder, \& S. Barnes (Eds.), Technology-enhanced learning: Principles and products (pp. 3-19). Dordrecht: Springer Netherlands.

Dishaw, M. T., Eierman, M. A., Iversen, J. H., \& Philip, G. (2013). An examination of the characteristics impacting collaborative tool efficacy: The uncanny valley of collaborative tools. Journal of Information Technology Education: Research, 12, 301-325. Retrieved from https://www.informingscience.org/Publications/1899

Dobao, A. F. (2012). Collaborative writing tasks in the L2 classroom: Comparing group, pair, and individual work. Journal of Second Language Writing, 21, 40-58. Retrieved from https://doi.org/10.1016/j.jslw.2011.12.002

Dyson, A. H. (Ed.). (2016). Child cultures, schooling, and literacy: Global perspectives on composing unique lives. New York: Routledge.

Golonka, E. M., Bowles, A. R., Frank, V. M., Richardson, D. L., \& Freynik, S. (2014). Technologies for foreign language learning: A review of technology types and their effectiveness. Computer Assisted Language Learning, 27, 70-105. doi:10.1080/09588221.2012.700315

Hadjerrouit, S. (2011). A collaborative writing approach to Wikis: Design, implementation, and evaluation. Issues in Informing Science and Information Technology, 8, 431-449. Retrieved from https://brage.bibsys.no/xmlui/bitstream/handle/11250/137909/Hadjerrouit 2011 Collaborative.pdf?se quence $=1 \&$ is Allowed $=\mathrm{y}$ 
Hennessy, S., Deaney, R., \& Ruthven, K. (2005). Emerging teacher strategies for mediating 'technologyintegrated instructional conversations’: A socio-cultural perspective. The Curriculum Journal, 16, 265-292. Retrieved from http://dx.doi.org/10.1080/09585170500256487

Hymes, D. (1974). Foundations in sociolinguistics: An ethnographic approach. Philadelphia: University of Pennsylvania Press.

Jones, R. W. (2007). Learning and teaching in small groups: Characteristics, benefits, problems and approaches. Anaesthesia and Intensive Care, 35, 587-592.

Kennedy, C., \& Miceli, T. (2013). In piazza online: Exploring the use of wikis with beginner foreign language learners. Computer Assisted Language Learning, 26, 389-411. Retrieved from http://dx.doi.org/10.1080/09588221.2013.770035

Kessler, G., Bikowski, D., \& Boggs, J. (2012). Collaborative writing among second language learners in academic web-based projects. Language Learning \& Technology, 16, 91-109. Retrieved from http://scholarspace.manoa.hawaii.edu/bitstream/10125/44276/1/16 01 kesslerbikowskiboggs.pdf

Lam, W. S. E. (2009). Multiliteracies on instant messaging in negotiating local, translocal, and transnational affiliations: A case of an adolescent immigrant. Reading Research Quarterly, 44, 377-397. doi: 10.1598/RRQ.44.4.5

Li, M., \& Zhu, W. (2013). Patterns of computer-mediated interaction in small writing groups using wikis. Computer Assisted Language Learning, 26, 61-82. Retrieved from http://dx.doi.org/10.1080/09588221.2011.631142

Li, N. (2013). Seeking best practices and meeting the needs of the English language learners: Using second language theories and integrating technology in teaching. Journal of International Education Research, 9, 217222.

Liu, S. H. J., \& Lan, Y. J. (2016). Social constructivist approach to web-based EFL learning: Collaboration, motivation, and perception on the use of Google Docs. Educational Technology \& Society, 19, 171-186. Retrieved from http://www.jstor.org/stable/jeductechsoci.19.1.171

National Governors Association Center for Best Practices \& Council of Chief State School Officers. (2010). Common Core State Standards for English language arts and literacy in history/social studies, science, and technical subjects. Washington, DC: Authors.

O’Dwyer, L. M., Russell, M., Bebell, D., \& Tucker-Seeley, K. R. (2005). Examining the relationship between home and school computer use and students' English/language arts test scores. Journal of Technology, Learning, and Assessment, 3. Retrieved from http://files.eric.ed.gov/fulltext/EJ848513.pdf

Seyyedrezaie, Z. S., Ghonsooly, B., Shahriari, H., \& Fatemi, H. H. (2016). Mixed methods analysis of the effect of Google Docs environment on EFL Learners' writing performance and causal attributions for success and failure. Turkish Online Journal of Distance Education (TOJDE), 17, 90-110. Retrieved from http://dergipark.ulakbim.gov.tr/tojde/article/viewFile/5000196874/5000170473

Shang, H. (2013). Factors associated with English as a foreign language university students writing anxiety. International Journal of English Language Teaching, 1, 1-12. Retrieved from http://www.eajournals.org/wpcontent/uploads/FACTORS-ASSOCIATED-WITH-ENGLISH-AS-A-FOREIGN-LANGUAGEUNIVERSITY-STUDENTS'-WRITING-ANXIETY.pdf

Sun, J. C.-Y. (2014). Influence of polling technologies on student engagement: An analysis of student motivation, academic performance, and brainwave data. Computers \& Education, 72, 80-89. Retrieved from https://doi.org/10.1016/j.compedu.2013.10.010

Suwantarathip, O., \& Wichadee, S. (2014). The effects of collaborative writing activity using Google Docs on students' writing abilities. The Turkish Online Journal of Educational Technology - TOJET, 13, 148-156.

Vass, E. (2002). Friendship and collaborative creative writing in the primary classroom. Journal of Computer Assisted Learning, 18, 102-110. doi:10.1046/j.0266-4909.2001.00216.x

Vygotsky, L. S. (1978). Mind in society. Cambridge, MA: Harvard University Press 
Warschauer, M. (1997). Computer-mediated collaborative learning: Theory and practice. Modern Language Journal, 81, 470-481. doi: 10.1111/j.1540-4781.1997.tb05514.x

Wigglesworth, G., \& Storch, N. (2009). Pair versus individual writing: Effects on fluency, complexity and accuracy. Language Testing, 26, 445-466. Retrieved from http://journals.sagepub.com/doi/pdf/10.1177/0265532209104670

Wong, L., Chai, C. S., \& Aw, G. P. (2017). Seamless language learning: Second language learning with social media. Comunicar, English Edition, 25, 9-20.

Wyatt-Smith, C., \& Elkins, J. (2008). Multimodel reading and comprehension in online environments. In J. Coiro, M. Knobel, C. Lankshear, \& D. J. Leu (Eds.), Handbook of research on new literacies (pp. 899-940). New York: Lawrence Erlbaum.

Zhou, W., Simpson, E., \& Domizi, D. P. (2012). Google docs in an out-of-class collaborative writing activity. International Journal of Teacbing and Learning in Higher Education, 24, 359-375. Retrieved from http://files.eric.ed.gov/fulltext/EJ1000688.pdf

Zhu, C. (2012). Student satisfaction, performance, and knowledge construction in online collaborative learning. Educational Technology \& Society, 15, 127-136. Retrieved from http://www.jstor.org/stable/jeductechsoci.15.1.127

\section{APPENDIX A - FULL ASSIGNMENTS GIVEN TO STUDENTS}

Topic A

Your job today is to work together to write an AXES paragraph about "The Diary of Anne

Frank" which answers the following question:

In "The Diary of Anne Frank" by Frances Goodrich and Albert Hackett, what character trait can be used to best describe Peter Van Daan?

Your work will be graded on the criteria in the AXES rubric.

\section{Topic B}

Your job today is to work together to write an AXES paragraph about "The Diary of Anne Frank" which answers the following question:

In "The Diary of Anne Frank" by Frances Goodrich and Albert Hackett, what character trait can be used to best describe Mr. Frank?

Your work will be graded on the criteria in the AXES rubric.

Topic C

Your job today is to work together to write an AXES paragraph about "The Diary of Anne Frank" which answers the following question:

In "The Diary of Anne Frank" by Frances Goodrich and Albert Hackett, what character trait can be used to best describe Anne?

Your work will be graded on the criteria in the AXES rubric. 


\section{APPENDIX B - READER LETTER ASSIGNMENT}

Hello wonderful student!

Today, you'll be working on a Reader Letter. What is that? A Reader Letter is a letter from you (the reader) to me (the teacher) that lets me know how you're doing so far with your Pleasure Reading this year.

It usually includes information like:

- How many books you've finished

- Which books you've loved

- Which characters you've identified with

- Connections that you're seeing in your reading

- Genres that you love (and hate!)

- Which books made you feel most excited

- Which authors you want to read more from

- Areas where you need help for next semester

The format is completely up to you. It can look like a normal letter, or you can choose to add pictures/emojis from Google to show me what you mean.

Here is the rubric I will use to assess your work:

\begin{tabular}{|l|l|l|l|}
\hline Category & 10 & 7 & 5 \\
\hline Thought & $\begin{array}{l}\text { The letter includes a lot } \\
\text { of information about the } \\
\text { reader's habits. }\end{array}$ & $\begin{array}{l}\text { The letter includes some } \\
\text { information about the } \\
\text { reader's habits. }\end{array}$ & $\begin{array}{l}\text { The letter doesn't ex- } \\
\text { plain the reader's habits. }\end{array}$ \\
\hline Voice & $\begin{array}{l}\text { The letter maintains a } \\
\text { personal voice or style. }\end{array}$ & $\begin{array}{l}\text { The letter sometimes } \\
\text { shows off the writer's per- } \\
\text { sonality. }\end{array}$ & $\begin{array}{l}\text { The letter doesn't have } \\
\text { much style or personali- } \\
\text { ty. }\end{array}$ \\
\hline $\begin{array}{l}\text { Grammar / } \\
\text { Mechanics }\end{array}$ & $\begin{array}{l}\text { There are few or no er- } \\
\text { rors. }\end{array}$ & There are some errors. & There are many errors. \\
\hline
\end{tabular}

\section{APPENDix C - Slanted ARTIClE AssignMENT SHEET}

Directions: When Ms. Darwin read the newspaper article about Philip Malloy, she exclaimed, "It's so slanted!" She felt that it made her out to be the villain, while defending the student's motivation for humming the national anthem. A slanted news article is one that is written so that it leans in favor of or against an issue, rather than reporting the facts in an objective way.

Go back into the novel and re-read Jennifer Stewart's article, "Suspended for Patriotism." Using that article as a model, pretend that Jennifer interviewed only the character that you have been researching to write her article. Write a new biased article about why Philip is suspended, using only details that your character would tell Jennifer Stewart.

Make sure you use the format of an article (who, what, when, where, why, how), report only the facts that your character would give to Jennifer, and maintain a professional tone or voice. 
You will be graded on these criteria:

\begin{tabular}{|l|l|l|l|l|}
\hline & 10 & 8 & 5 & 0 \\
\hline Bias & $\begin{array}{l}\text { The article includes in- } \\
\text { formation only from the } \\
\text { character of focus. It } \\
\text { shows what that character } \\
\text { would think and believe. }\end{array}$ & $\begin{array}{l}\text { The article includes in- } \\
\text { formation that is mostly } \\
\text { from the character of fo- } \\
\text { cus, but may also contain } \\
\text { additional information. }\end{array}$ & $\begin{array}{l}\text { It is difficult to determine } \\
\text { who is the character of } \\
\text { focus from the article. } \\
\text { The information comes } \\
\text { from many sources. }\end{array}$ & $\begin{array}{l}\text { No at- } \\
\text { tempt } \\
\text { made. }\end{array}$ \\
\hline Tone & $\begin{array}{l}\text { The article has the tone } \\
\text { of a professional news- } \\
\text { paper. }\end{array}$ & $\begin{array}{l}\text { The article includes some } \\
\text { phrases that do not match } \\
\text { the tone of a professional } \\
\text { newspaper. }\end{array}$ & $\begin{array}{l}\text { The article does not } \\
\text { sound much like a pro- } \\
\text { fessional news article. }\end{array}$ & $\begin{array}{l}\text { No at- } \\
\text { tempt } \\
\text { made. }\end{array}$ \\
\hline Grammar & $\begin{array}{l}\text { There are few or no er- } \\
\text { rors in the article. }\end{array}$ & $\begin{array}{l}\text { There are some errors in } \\
\text { the article. }\end{array}$ & $\begin{array}{l}\text { There are many errors in } \\
\text { the article. }\end{array}$ & $\begin{array}{l}\text { No at- } \\
\text { tempt } \\
\text { made. }\end{array}$ \\
\hline
\end{tabular}

\section{APPENDIX D - RUBRIC FOR AXES PARAGRAPHS}

\begin{tabular}{|l|l|l|l|}
\hline Category & 3 & 2 & 1 \\
\hline Assertion & $\begin{array}{l}\text { Responds to writing } \\
\text { prompt by clearly stat- } \\
\text { ing the given assertion } \\
\text { or something similar. }\end{array}$ & $\begin{array}{l}\text { Assertion is unclear or } \\
\text { vague. }\end{array}$ & Assertion is missing. \\
\hline Example & $\begin{array}{l}\text { Clearly states one ex- } \\
\text { ample that supports the } \\
\text { assertion. The example } \\
\text { includes a transition } \\
\text { word, context, and } \\
\text { proper citation. }\end{array}$ & $\begin{array}{l}\text { States one example that } \\
\text { somewhat supports the } \\
\text { assertion. The example } \\
\text { does not have all of the } \\
\text { required pieces. }\end{array}$ & $\begin{array}{l}\text { The example is unclear, } \\
\text { missing, or does not } \\
\text { support the assertion. }\end{array}$ \\
\hline Explanation & $\begin{array}{l}\text { Each example is ex- } \\
\text { plained with sufficient } \\
\text { details. }\end{array}$ & $\begin{array}{l}\text { Explanations are vague } \\
\text { and may lack important } \\
\text { details about the topic. }\end{array}$ & $\begin{array}{l}\text { Explanations are insuf- } \\
\text { ficient or are missing } \\
\text { completely. }\end{array}$ \\
\hline Significance & $\begin{array}{l}\text { Clearly states why it is } \\
\text { important to believe } \\
\text { the writer. }\end{array}$ & $\begin{array}{l}\text { Vaguely states why it is } \\
\text { important to believe the } \\
\text { writer. }\end{array}$ & Significance is missing. \\
\hline $\begin{array}{l}\text { Grammar, Me- } \\
\text { chanics, and } \\
\text { Formatting }\end{array}$ & Little to no errors. & Some errors. & Many errors. \\
\hline $\begin{array}{l}\text { Total points: } \\
\text { /15 }\end{array}$ & & & \\
\hline
\end{tabular}




\section{APPENDIX E - LIKERT SCALE SURVEY}

Please show your level of agreement to each statement by checking the appropriate box. 5 is strongly agree, 4 is agree, 3 is neutral or undecided, 2 is disagree, 1 is strongly disagree. Your responses will remain anonymous.

\begin{tabular}{|c|c|c|c|c|c|}
\hline Statement & 5 & 4 & 3 & 2 & 1 \\
\hline Working face-to-face was easiest. & & & & & \\
\hline I felt successful on the assignments using Google Docs. & & & & & \\
\hline Everyone in my team contributed more when using Google Docs. & & & & & \\
\hline I had something to contribute to my team on these assignments. & & & & & \\
\hline I learned from my team members when using Google Docs. & & & & & \\
\hline Working anonymously caused everyone to participate more. & & & & & \\
\hline Google Docs helped my group create a better final assignment. & & & & & \\
\hline Working at the same time as my team members was helpful. & & & & & \\
\hline I liked being able to comment and revise the document online. & & & & & \\
\hline I would like to use Google Docs for more assignments in the future. & & & & & \\
\hline
\end{tabular}

\section{BIOGRAPHIES}

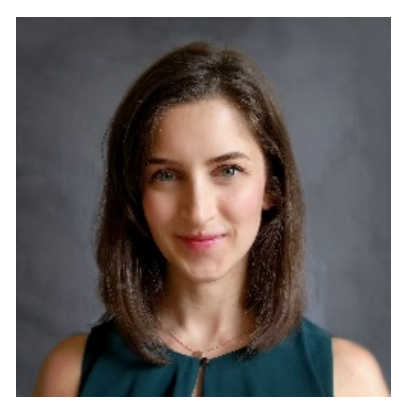

Megan Woodrich earned a Master of Arts Degree in Education from San Francisco State University in 2016. Prior to that, she completed a Bachelor's Degree in Linguistics from the University of California San Diego and a Single Subject teaching credential from CSU Channel Islands. Her focus is on meeting the needs of English Language Learners across content areas. Megan is currently serving as a Teacher on Special Assignment for English Learner Intervention in the South San Francisco Unified School District.

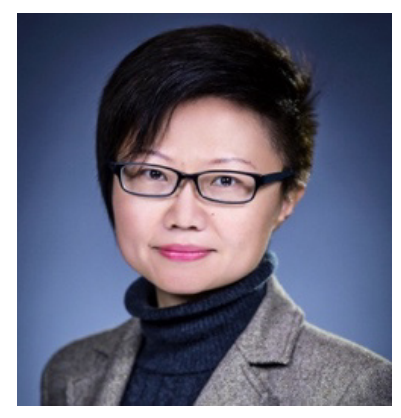

Yanan Fan received a Ph. D. in Curriculum, Teaching, and Educational Policy from Michigan State University in 2006. Her research interests include literacy development among immigrant adolescents and teacher preparation for linguistically diverse learners in public schools. Yanan is currently an associate professor in the Department of Secondary Education at San Francisco State University. 